\title{
骨移植を併用した人工膝関節置換術の経験
}

鹿児島生協病院整形外科
$\begin{array}{ccccc}\text { 重 } & \text { 盛 } & & \text { 廉・行 } \text { 田 義 } & \text { 仁 } \\ \text { 駿 } & \text { 河 } & \text { 保 } & \text { 彰・前 } & \text { 田 宏 志 }\end{array}$

\section{Clinical Experience of Total Knee Replacement with Bone Graft}

by

\section{Osamu Shigemori, Yoshihito Yukita, Yasuaki Suruga and Hiroshi Maeda}

Department of Orthopedic Surgery, Kagoshima Seikyo Hospital, Kagoshima, Japan

Bone grafting of tibial defects in primary total knee arthroplasty was performed in four knees ( 3 patients). All three patients had rheumatoid arthritis and had been treated by intra-articular steroid injection. All tibial defects were in medial plateau and were filled with bone from the adjacent femoral condyle. The bone was held in place by a screw and/or K-wires. In all knees, clinically bony union was seen and no collapse was present.

\section{は じめに}

慢性関節リウマチ $(\mathrm{RA})$ の膝病変に対する人工膝関 節置換術 (TKR) についての数多くの報告があるが, その中で, 最近, 脛骨顆部の骨欠損を伴った高度の内・ 外反変形に対する TKR の報告が増えている.こうした 症例は，ステロイドの関節内注入などを背景として， RA ばかりでなく,変形性膝関節症や他疾患でもみられ るようになってきた。われわれも, RA 嚗の脛骨内顆骨 欠損例に対し,骨移植を併用した TKR を行い, 短期で はあるが，比較的良好な術後成績が得られたので報告 する。

\section{対象}

症例は脛骨内顆に骨欠損を伴ったRA 3 例 4 膝で, 全例女性であった(表 1 )。手術時平均年令は 61 才で, $R A$ 罹病期間は平均 19 年 (17 20 年) で, Stage 分類 では全例がIVで, Class 分類ではIIIが 2 例, IVが 1 例で あり，全例ステロイド関節内注入歴を有していた。術 後の平均観察期間は 2 年 2 力月 ( 1 年〜 3 年 1 力月)
表 1 症例

\begin{tabular}{|c|c|c|c|c|c|c|}
\hline 症 例 & 年撂 & 性 & 疾患 & 骨 欠損部位 & $F T A$ & 脛骨コンポーネント厚 \\
\hline \multirow[t]{2}{*}{1} & \multirow[t]{2}{*}{66} & \multirow[t]{2}{*}{$\mathrm{F}$} & \multirow[t]{2}{*}{ RA } & & $194^{\circ}$ & $\begin{array}{l}7 \mathrm{~mm} \\
\text { (ステム付) }\end{array}$ \\
\hline & & & & & $205^{\circ}$ & $\begin{array}{l}7 \mathrm{~mm} \\
\text { (ステム付) }\end{array}$ \\
\hline 2 & 50 & $\mathrm{~F}$ & RA & & $182^{\circ}$ & $7 \mathrm{~mm}$ \\
\hline 3 & 66 & $\mathrm{~F}$ & RA & & $188^{\circ}$ & $7 \mathrm{~mm}$ \\
\hline
\end{tabular}

であった.

手術では，健常な軟骨下骨を残すため，脛骨上端部 はできるだけ上方で骨切りを行い, あらかじめ, 移植 母床はドリルや鋭匙で硬化した骨を除去し，大腿骨顆 部後方部分などのブロック状の骨を重ねて移植し，骨 ネジ, Kワイヤーで固定した.人工関節は PCA を用い, 脛骨板はもっとも薄い $7 \mathrm{~mm}$ 厚のものを使用した。

\section{臨 床 成 績}

術後成績は，日整会 $\mathrm{RA}$ 膝治療判定基準を用いて評 価した。総合点は術前平均 32 点 (26〜 45 点) が調查時 
平均 67 点 (56〜 80 点) と改善し, 患者の満足度も高か った。歩行能力でも， 2 例 3 膝は杖なし独歩が可能と なり,歩行不能だった 1 例も室内歩行が可能となった。 㯟の ROM は， 4 膝とも $90^{\circ}$ 前後となり, FTA は術前 平均 $192^{\circ}\left(182 \sim 205^{\circ}\right)$ が術後 $173^{\circ}\left(172 \sim 175^{\circ}\right)$ と良好 なアラインメントとなった(図 1 )。2 例 3 膝について 症例報告する。

症例 $1 ： 66$ 才，女性. Stage IV Class III

20 年前 RA 発症. 昭和 59 年夏より両膝関節痛増強 し,他医にて両側とも 10 回程度のステロイド関節内注 入を受けた。 60 年 7 月より両膝の変形と不安定性著明 となり, 同年 9 月当科受診. 術前, 両膝関節とも脛骨
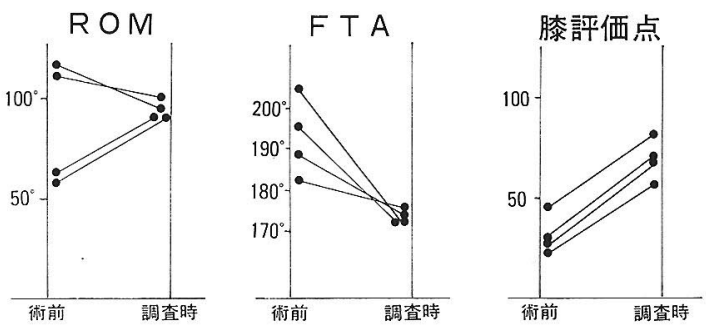

図 1 術前, 調查時の臨床評価

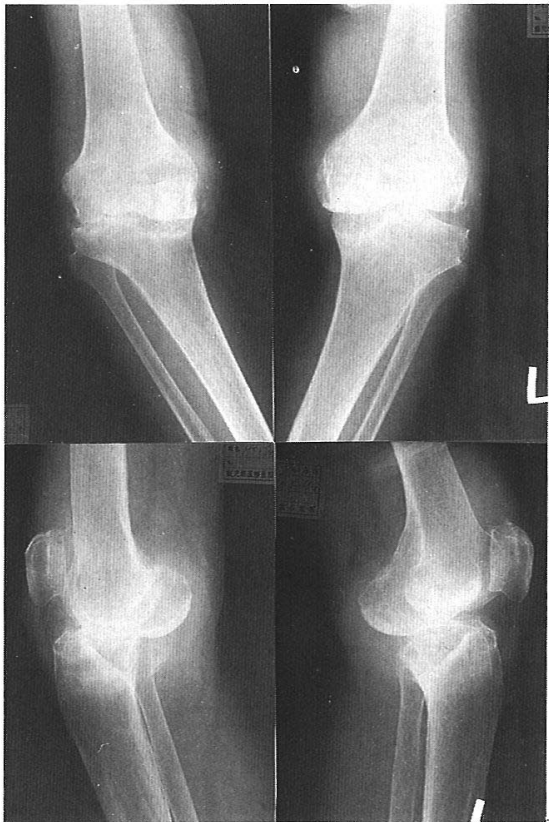

図 2 症例 1 : 術前 $\mathrm{X}$ 線像

両膝とも脛骨内顆後方に骨欠損があり，高度な 内反変形を示している。
内顆後方に大きな骨欠損がみられ, FTA は右 $194^{\circ}$, 左 $205^{\circ}$ で，右膝では大腿骨外顆，脛骨外顆にも骨欠損が みられた（図 $2 ， 3$ )。右側の TKR では，大腿骨遠位 部，脛骨上端部の切除骨片も利用し，3枚を重ねて脛 骨内顆骨欠損部に移植，また，大腿骨外顆にも骨移植 し; 人工関節を挿入, セメント固定を行った。左側に
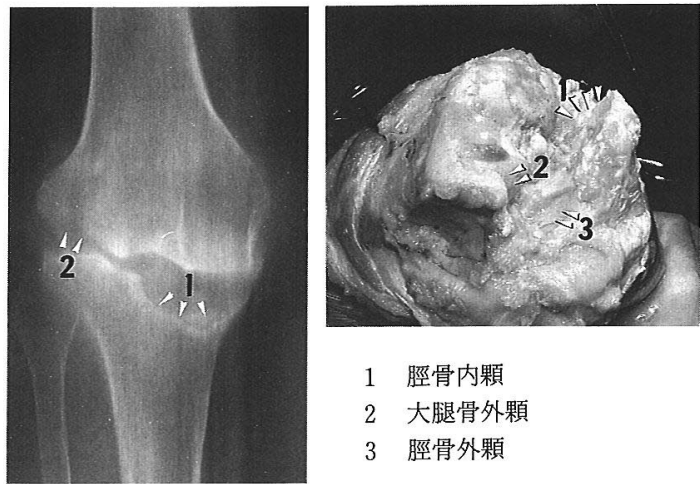

図 3 症例 1 : 断層撮影と術中所見 (右膝) 脛骨内顆ばかりでなく，大腿骨外顆，脛骨外顆 にも骨欠損がみられる。

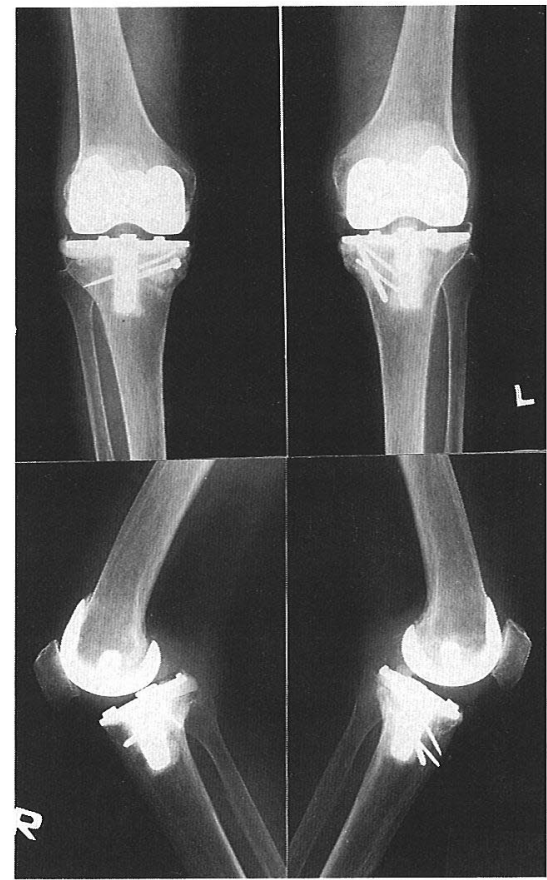

図 4 症例 1 : 術後X線像 術後FTA は, 右 $173^{\circ}$, 左 $172^{\circ}$ と改善した。 


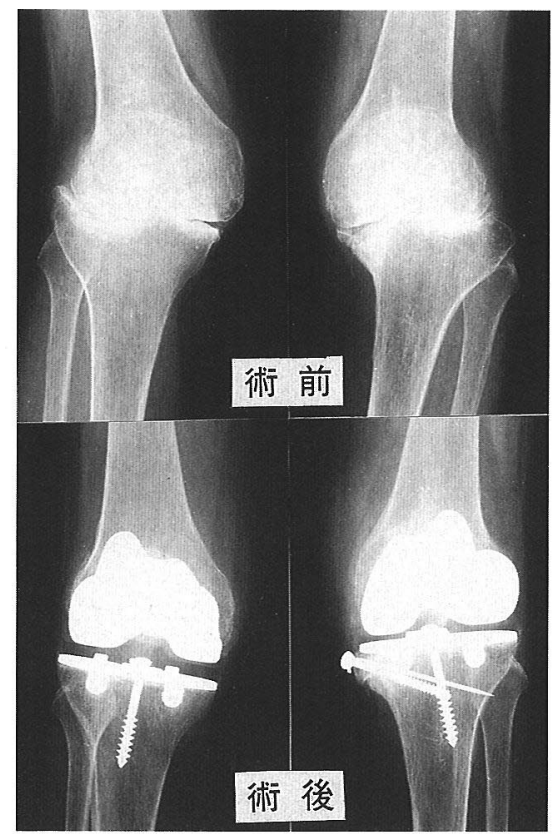

図 5 症例 2 : 術前・術後X線像 右膝は脛骨外顆に中心型欠損を，左膝は脛骨内 顆に周辺型欠損を認める。

も骨移植を併用し, TKR を行い, 術後 FTA は右 $173^{\circ}$, 左 $172^{\circ}$ となった(図 4 ). 術後 8 週で荷重を開始したが, 移植骨の圧潰もなく, 骨瘾合し, 術後 3 年を経過した 現在も, 膝のアラインメントは良好で, 杖なし独歩を 維持している.膝評価点は, 両膝とも, 術前 29 点が調 查時 68 点まで改善した。

症例 $2: 50$ 才，女性. Stage IV Class III

17 年前, 両䐂関節痛にて RA 発症. 13 年前, 右膝は 滑膜切除術を行っている. ステロイド関節内注入歴も あり，ステロイド剤の内服も継続していたが，膝関節 痛増強するため, 当科へ紹介入院となる。術前, 右膝 は脛骨外顆に中心型欠損があり, FTA $160^{\circ}$, 左滕は脛 骨内顆に骨欠損を認めるも, 外側関節裂隙も消失し, FTA は $182^{\circ}$ と内反変形は軽度であった (図 5 )。左側 の TKR では, 大腿骨顆部後方部分を重ね, 骨移植し, Resurfacing type の脛骨板をセメントレスで使用した

(図 5 )。両側同時 TKR 後 1 年 9 力月の現在, $1 \mathrm{~km}$ 以 上の歩行が可能で, 左膝の評価点は, 術前 45 点から調 查時 80 点へと改善した。
考察

脛骨に骨欠損を有する膝関節に対するTKRについて は，いろいろな見解があるが，最近では，骨移植を併 用したTKRで良好な術後成績が得られているとの報告 が多いようである2 ${ }^{2) 46)}$. 従来は, 蝶番型 TKR や厚め の脛骨板の使用，また，骨欠損部に対するセメント充 填や段違い脛骨板の使用にて対処してきた。しかし， 膝屈曲時の回旋要素にも対応する改良型もみられるが, 蝶番型 TKR は“弛み”の問題や，骨切除量が多いなど の問題があり，厚めの脛骨板を用いる方法は，健常な 軟骨下の硬い骨も切除することになり，脛骨板を支え る断面積が減少するなどの問題があり ${ }^{2336)}$, セメント充 填や段違い脛骨板の使用は，力学的な問題が指摘され ている(1)336).

骨移植は，移植骨の生着までに時間を要する欠点も あるが，生着すれば，生体力学的に理想的なスペーサ 一である点 ${ }^{6}$, 二次的手術を考えて，少しでも骨量を温 存しようとする点的で, 最良の方法のひとつである。ま た，骨移植を併用すれば，アラインメントの矯正も容 易であり ${ }^{3)}$, 手術時に膝のアラインンメントを軽度外反 $\left(5 \sim 8^{\circ}\right)^{2)}$ に調製することができる.また，特殊な人 工関節を使用しない TKR であるという利点も大きい2).

荷重開始時期については，移植骨の強度やその固定 法, 骨瘾合の時期など諸要素がかかわっており, 12 週 以降 ${ }^{5)}$ とする報告もあれば,通常の TKR と同様してい る2) との報告もある。われわれも, 荷重開始を $5 \sim 8$ 週 と遅らせているが，アラインメントと移植骨の適合性 が良好なものは早期荷重も可能と考えている。

\section{ま と め}

1. 脛骨内顆に骨欠損を認めたRA 3 例 4 膝に対 し，骨移植を併用した TKR を行った。

2. 4 滕とも移植骨は骨瘾合し, 術後成績も良好で あった。

3. 4 膝とも, 術前の内反変形が, 術後は軽度外反 位 $\left(5 \sim 8^{\circ}\right)$ と良好なアラインメントとなった。

\section{参 考 文 献}

1) Brooks, P. J. et al. : Tibial component fixation in deficient tibial bone stock. Clin. Orthop., 184: 302308, 1984.

2) Dorr, L. D. et al. : Bone graft for tibial defects in total knee arthroplasty. Clin. Orthop., 205 : 153-165, 
1986.

3）堀内静夫・他：骨移植を併用した人工膝関節置換術の 経験。神奈川関節外科研究会誌, $2: 41-46,1987$.

4）井上 一・他：骨移植併用による人工膝関節置換術. 日関外誌, $3: 227-232,1984$.

5) Laskin, R. S.: Fixed varus deformity. Total Knee Arthroplasty A Comprehensive Approach, pp. 179192, Williams and Wilkins, Baltimore/London, 1984.

6）龍順之助・他：骨移植を併用した人工膝関節置換術に ついで. 臨整外, 19:999-1006, 1984.

質 問大分医科大学 鳥巣 岳彦

症例 1 では荷重開始を 8 週としているが, 根拠はあ
るか.骨移植例でも, 通常の TKR と同様の荷重開始で よいのではないか.

解 答鹿児島生協病院 重盛 廉

骨欠損の程度によっては, 通常の TKR と同様に荷重 を開始してもよいとの報告もあり，最近は，われわれ も荷重時期を早めている. 術後のアラインメント, 移 植骨の状態が良好ならば, 早期の荷重も可能と考えて いる。 